INDONESIA ACCOUNTING JOURNAL

VOLUME 2, NUMBER 1, YEAR 2020

${ }^{1}$ Corresponding author

Jurusan Akuntansi

Fakultas Ekonomi dan Bisnis

Universitas Sam Ratulangi

Jl. Kampus UNSRAT

Manado, Indonesia, 95115

E-mail: t.rosiana14@gmail.com

${ }^{2,3}$ Jurusan Akuntansi

Fakultas Ekonomi dan Bisnis

Universitas Sam Ratulangi

Jl. Kampus UNSRAT

Manado, Indonesia, 95115

Article info:

Received 24 January 2020

Accepted 25 January 2020

Available online 27 January 2020

Keywords: management accounting information systems; total quality management; product quality

JEL Classification: I15, I21

DOI: http://doi.org/10.3240o/iaj.27705

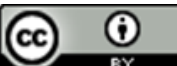

\section{Penerapan sistem informasi akuntansi manajemen terhadap pengendalian kualitas produk pada Holland Bakery Manadoc}

\author{
Tirsa Rosiana Lini Wala ${ }^{1}$ \\ Grace B. Nangoi ${ }^{2}$ \\ Stanley Kho Walandouw ${ }^{3}$
}

\begin{abstract}
Holland Bakery is a brand for modern bakery franchise networks with premium quality. Holland Bakery was first established in 1987 in Jakarta, under the auspiece of PT. Mustika Citra Rasa. Holland Bakery is the only Disney character licensee bakery in Indonesia. Holland Bakery has 22 branches that manage more than 400 outlets and will continue to be expanded nationally to other cities. The purpose of this research is to analyze the application of Management Accounting Information System to Product Quality Control in Holland Bakery Manado. This type of research is qualitative descriptive research. Based on the result of research that has been done, in the process of applying Management Accounting Information System to Product Quality Control in Holland Bakery Manado, researchers found their application of Total Quality Management in their business activities. With the exixtence of TQM in its business processes, the company can run smoothly and show positive results for the company.
\end{abstract}

\section{Pendahuluan}

Untuk mencapai kualitas informasi akuntansi yang maksimal sesuai yang diharapkan oleh perusahaan, maka para manajer dituntut untuk semaksimal mungkin dapat mendayagunakan keahliannya berupa pemahaman metode dan teknik akuntansi manajemen yang terus mengalami perkembangan, sehingga perusahaan dapat beroperasi seefisien mungkin untuk mencapai tujuan yang telah ditetapkan sebelumnya, dan menghindari penyalahgunaan wewenang dan pemborosan dana. Untuk menghadapi permasalahan tersebut diperlukan suatu sistem pelaporan intern yang memadai. Dalam sistem pelaporan intern ini diperlukan akuntansi manajemen.

Akuntansi manajemen adalah sistem akuntansi yang berkaitan dengan ketentuan dan penggunaan informasi akuntansi untuk manajer atau manajemen dalam suatu organisasi dan untuk memberikan dasar kepada manajemen untuk membuat keputusan bisnis yang akan memungkinkan manajemen akan lebih siap dalam pengelolaan dan melakukan fungsi pengendalian (contro). Akuntansi manajemen adalah salah satu bidang ilmu akuntansi yang mempelajari bagaimana cara menghasilkan informasi keuangan untuk pihak manajemen yang selanjutnya akan digunakan untuk pengambilan keputusan (Sujarweni, 2015:2). Umumnya informasi yang dihasilkan sifatnya lebih dalam dan biasanya tidak dipublikasikan. Manajemen adalah seni untuk melakukan sesuatu guna mencapai tujuan dengan bantuan orang lain. Dalam perusahaan pengelolaan manajemen untuk mencapai tujuan perlu ditempatkan manajermanajer yang akan melakukan pengelolaan dalam departemen-departemennya.

Kualitas produk yang baik adalah salah satu kunci keberhasilan perusahaan. 
Keberhasilan perusahaan tak lepas dari sistem informasi yang terkontrol dengan baik dalam perusahaan. Dengan adanya sistem informasi, perusahaan akan dengan mudah menjalankan fungsi-fungsi manajemen dengan efisien dan efektif sehingga perusahaan dapat mencapai tujuannya yang telah ditetapkan sebelumnya. Menurut Lupiyoadi dan Hamdani (2009:176) menjelaskan bahwa: "kualitas produk adalah proses produksi suatu barang, dimana kualitas produk yang diberikan oleh perusahaan dapat menciptakan suatu persepsi positif dari pelanggan terhadap perusahaan dan menghasilkan suatu kepuasan serta loyalitas pelanggan". Untuk menghasilkan produk dengan kualitas yang terbaik guna meningkatkan kinerja manajerial diperlukan upaya perbaikan berkesinambungan terhadap kemampuan manusia, proses, dan lingkungan. Salah satu metode yang dapat digunakan untuk memperbaiki kemampuan komponenkomponen tersebut secara berkesinambungan adalah dengan menerapkan Total Quality Management (TQM).

Penelitian mengenai Sistem Informasi Akuntansi Manajemen terhadap pengendalian kualitas produk telah banyak dilakukan pada berbagai jenis perusahaan dan memberikan hasil yang beragam. Penelitian Mawadah dan Muchayatin (2018) menunjukkan bahwa keberadaan sistem informasi manajemen akuntansi untuk kontrol kualitas produk mendukung produksi, kontrol kualitas, jaminan kualitas, dan kontrol produksi dalam menjalankan setiap kegiatan pada bagian mereka dalam menghasilkan produk yang sesuai dengan standar kualitas. Berbeda dengan penelitian yang dilakukan oleh Butarbutar et al. (2017) bahwa hasil dari penerapan sistem akuntansi manajemen telah menunjukkan perannya sebagai alat dalam mengendalikan kualitas produk. Sedangkan Tengor et al. (2016) mengemukakan hasil penelitannya bahwa sistem akuntansi manajemen berpengaruh positif dan signifikan terhadap pengendalian biaya kualitas produk.
Sistem informasi akuntansi manajemen merupakan sistem informasi bagi manajer dalam perusahan. Penerapan sistem informasi akuntansi manajemen sangat penting bagi perusahaan sebagai alat pengendalian kualitas produk. Dengan adanya sistem informasi akuntansi manajemen dalam perusahaan dapat mempermudah proses kegiatan usaha/bisnis dan perusahaan dapat bersaing dipasaran dengan memberikan produk yang berkualitas baik. Produk yang berkualitas baik banyak dicari oleh para konsumen untuk dibeli dan dikonsumsi sehingga memberikan keuntungan bagi perusahaan.

\section{Tinjauan pustaka}

Konsep akuntansi. Secara umum akuntansi dapat didefinisikan sebagai suatu proses identifikasi, pengukuran dan pengkomunikasian informasi ekonomi yang menghasilkan informasi ekonomi yang berguna bagi pembuatan kebijakan dan keputusan oleh pemakainya (Samryn, 2012: 4). Akuntansi adalah proses dari transaksi yang dibuktikan dengan faktur, lalu dari transaksi dibuat jurnal, buku besar, neraca lajur, sehingga menghasilkan informasi dalam bentuk laporan keuangan yang dapat digunakan oleh pihak-pihak tertentu (Sujarweni, 2015:1). American Accounting Association mendefinisikan akuntansi sebagai suatu proses pengidentifikasian, pengukuran dan pelaporan informasi ekonomi, yang memungkinkan adanya penilaian dan pengambilan keputusan yang jelas dan tegas bagi mereka yang menggunakan informasi tersebut. Menurut American Insitute of Certified Public Accounting (AICPA) dalam mendefsinisikan akuntansi sebagai seni pencatatan, penggolongan, dan peringkasan transaksi dan kejadian yang bersifat keuangan dengan cara yang berdaya guna dan dalam bentuk satuan uang, dan penginterpretasian hasil proses tersebut.

\section{Konsep akuntansi manajemen.} Akuntansi manajemen merupakan cabang ilmu akuntansi yang mempelajari bagaimana cara menghasilkan informasi keuangan bagi pihak manajemen atau pihak intern perusahaan yang selanjutnya digunakan 
untuk pengambilan keputusan. Umumnya informasi yang dihasilkan lebih dalam dan biasanya tidak dipublikasikan (Sujarweni, 2015:1). Akuntansi manajemen merupakan suatu kegiatan yang menghasilkan berbagai informasi yang akan dikonsumsi/digunakan oleh pihak internal (manajemen) guna melaksanakan berbagai fungsi manajemen, mulai dari fungsi perencanaan, fungsi pengarahan dan motivasi karyawan, fungsi koordinasi, fungsi pengendalian dan pengawasan, fungsi penilaian kerja, dan fungsi pembuatan keputusan (Krismiaji dan Aryani, 2011 : 15). Hansen dan Mowen (2012: 19) menyatakan bahwa akuntansi manajemen adalah mengidentifikasi, mengumpul, mengukur, mengklasifikasi, dan melaporkan informasi yang bermanfaat bagi pengguna internal dalam merencanakan pengendalian dan pengambilan keputusan.

Konsep sistem informasi akuntansi manajemen. Informasi akuntansi manajemen dibutuhkan dan digunakan dalam semua lingkup manajemen. Informasi akuntansi manajemen membantu para manajer dalam menjalankan tugasnya/perannya dalam melakukan aktivitas perencanaan, pengendalian, dan pengambilan keputusan. Supriyono (2015) menyatakan bahwa "sistem informasi akuntansi manajemen merupakan suatu perangkat manusia dan sumber-sumber modal dalam perusahaan/organisasi yang bertanggungjawab untuk menghasilkan dan menyebarkan suatu informasi yang telah dipertimbangkan dengan relevan dalam pembuatan keputusan manajemen".

Total quality management (TQM). Menurut Krismiaji dan Aryani (2011: 9), "Total Quality Management (manajemen kualitas total/manajemen mutu terpadu) adalah perbaikan berkelanjutan dalam kualitas, produktivitas dan efektivitas dengan cara menetapkan tanggung jawab manajemen terhadap proses dan hasil". Nasution (2015:17) menjelaskan bahwa Total Quality Management adalah suatu pendekatan dalam menjalankan usaha yang mencoba untuk memaksimumkan daya saing organisasi melalui perbaikan-perbaikan secara terus-menerus atas produk, jasa, tenaga kerja, proses dan lingkungannya. Sumarsan (2013:185) menyatakan bahwa manajemen mutu terpadu (TQM) adalah sebuah metode dengan budaya, sikap dan struktur organisasi dari sebuah perusahaan yang berusaha untuk menyediakan pelanggan dengan produk dan jasa yang memenuhi atau melebihi kebutuhan mereka dengan melibatkan manajemen dengan seluruh karyawan dalam perbaikan terus menerus terhadap perbaikan produk dan jasa yang diproduksi dengan mengurangi kerugian akibat praktik-praktik pemborosan, pembuangan dan cacat.

\section{Karakterisrtik Total Quality} Management. Krismiaji dan Aryani (2011:10) menyatakan bahwa ada dua karakteristik pokok TQM adalah (1) memfokuskan pada pelayanan pelanggan dan (2) penggunaan tim dalam memecahkan persoalan secara sistematik. Sutarto (2015:6), ada 10 karakteristik utama dari Total Quaility Management yaitu: (1) fokus pelanggan. Pelanggan berperan penting dalam proses bisnis. Hal ini berlaku untuk pelanggan ekstrnal maupun internal. Pelanggan eksternal menentukan mutu produk/jasa yang diharapkan, sedangkan pelanggan internal membantu menentukan mutu personil, proses, dan lingkungan yang diperlukan untuk menghasilkan produk/jasa yang diharapkan; (2) obsesi mutu. Pelanggan eksternal dan pelanggan internal adalah penentu mutu, dengan mutu yang tertentu tersebut, institusi harus terobsesi untuk memenuhi bahkan melampaui standar mutu yang ditentukan tersebut. Semua individu di institusi pada semua level melakukan tugas dan kewajiban dan berupaya bagaimana dapat bekerja lebih baik; (3) pendekatan ilmiah. Makna utama dari pendekatan ilmiah adalah pengambilan kesimpulan berdasarkan data. Pada organisasi pada umumnya, pengambilan keputusan biasanya ditetapkan lebih dominan bedasarkan keinginan pimpinan. Penggunaan pendekatan ilmiah dalam merumuskan prosedur kerja, pengambilan kesimpulan dan penyelesaian masalah. Berarti perlu dikumpulkan data dan informasi kinerja institusi, dianilisis dan disimpulkan yang selanjutnya dipakai sebagai 
basis dalam menentukan patok duga (benchmarks), memonitor kinerja, dan menentukan program peningkatan mutu; (4) komitmen jangka panjang. TQM merupakan paradigma baru dalam melaksanakan bisnis. Untuk itu dibutuhkan budaya perusahaan yang baru pula. Komitmen jangka panjang sangat penting guna mengadakan perubahan perubahan budaya agar penerapan TQM dapat berjalan dengan sukses; (5) kerjasama tim (teamwork). dalam organisasi yang menerapkan TQM, kerja sama tim, kemitraan dan hubungan dijalin dan dibina dengan baik antara karyawan perusahaan maupun dengan pemasok lembaga-lembaga pemerintah dan masyarakat sekitarnya; (6) perbaikan sistem secara berkesinambungan. Setiap produk atau jasa yang dihasilkan dengan memanfaatkan proses-proses tertentu didalam suatu sistem atau lingkungan. Oleh karena itu, sistem yang sudah ada perlu diperbiki secara terus menerus agar kualitas yang dihasilkan dapat meningkat; (7) pendidikan dan pelatihan merupakan faktor yang fundamental. Setiap orang diharapkan dan didorong untuk terus belajar, yang tidak ada akhirnya dan tidak mengenal batas usia. Dengan belajar, setiap orang dalam perusahaan dapat meningkatkan keterampilan teknis dan keahlian profesionalnya; (8) kebebasan yang terkendali. Dalam TQM, keterlibatan dan pemberdayaan karyawan dalam pengambilan keputusan dan pemecahan masalah merupakan unsur yang sangat penting. Hal ini dikarenakan unsur tersebut apat meningkatkan rasa memiliki dan tanggung jawab karyawan terhadap keputusan yang dibuat; (9) kesatuan tujuan. Agar TQM dapat diterapkan dengan baik, maka perusahaan harus memiliki kesatuan tujuan. Dengan demikian setiap usaha dapat diarahkan pada tujuan yang sama. Namun hal ini tidak berarti bahwa harus selalu ada persetujuan atau kesepakatan antara pihak manajemen dan karyawan mengenai upah dan kondisi kerja; dan (10) adanya keterlibatan dan pemberdayaan karyawan. Keterlibatan dan pemberdyaan karyawan merupakan hal yang penting dalam penarapan TQM. Pemberdayaan bukan sekedar melibatkan karyawan tetapi juga melibatkan mereka dengan memberikan pengaruh yang sungguh berarti. Manfaat dari Total Quality Management adalah memperbaiki kinerja manajerial dalam mengelola perusahaan agar dapat meningkatkan penghasilan perusahaan. Setiap perusahaan memiliki tujuan pokok untuk meningkatkan kualitas atau mutu produknya. Peningkatan kualitas atau mutu produk ini sangat penting bagi keberlangsungan perusahaan agar mendapat kepercayaan konsumen. Menurut Nasution (2015) manfaat TQM dapat dikelompokkan menjadi dua, yaitu dapat memperbaiki posisi persaingan dan meningkatkan keluaran yang bebas dari kerusakan.

Kualitas produk. Kotler dan Keller (2009) menyatakan kualitas produk adalah kemapuan suatu produk untuk melaksanakan fungsinya, yang meliputi daya tahan, keandalan, ketepatan, kemudahan operasi, dan perbaikan serta atribut yang bernilai lainnya. Kualitas produk menurut Tjiptono (2008) ada 8 dimensi, yaitu: (1) kinerja (performance), merupakan suatu karakterstik operasi dan produk inti (core product) yang dibeli, misalnya kecepatan, kemudahan, dan kenyamanan dalam penggunaan produk; (2) daya tahan (durability), yang artinya daya tahan dari produk yang dipakai atau digunakan (usia produk), yaitu jumlah pemakaian suatu produk sebelum produk tersebut digantikan dengan produk yang baru atau rusak. produk yang awet dapat dikatakan berkualitas dibandingkan dengan produk yang mudah rusak dan cepat habis; (3) kesesuaian dengan spesifikasi (conformance to specification), yaitu sejauh mana karakteristik desain produk dan pengoperasiannya yang telah memenuhi standar yang sudah ditetapkan sebelumnya; (4) fitur (features), merupakan karakteristik atau ciri khas yang ditambahkan untuk melengkapi manfaat dasar suatu produk. Fitur ini berdasarkan pilihan bagi konsumen. Fitur ini bisa meningkatkan kualitas produk bagi perusahaan jika kompetitor atau pesaing tidak memiliki fitur tersebut; (5) reliabilitas (reliability), yaitu meminimalisasi suatu kerusakan produk atau gagal pakai, misalnya 
pengawasan kualitas dan desain, standar karakteristik operasional kesesuaian dengan spesifikasi suatu produk; (6) estetika (aesthetic), yaitu daya tarik produk terhadap panca indra, misalkan bentuk fisik, model atau desain yang artistik, warna dan sebagainya; (7) kesan kualitas (perceived quality) yaitu persepsi konsumen terhadap keseluruhan kualitas atau keunggulan suatu produk; dan (8) kemudahan perawatan dan memperbaiki (serviceability) yaitu kualitas produk dapat ditentukan berdasrkan kemampuan dalam memperbaiki produk: mudah, cepat, dan kompeten.

\section{Metode penelitian}

Jenis penelitian yang digunakan yaitu penelitian deskriptif kualitatif. Data-data yang diteliti berupa kata-kata atau kalimat, gambar dan bukan angka-angka karena didasarkan pada penelitian kualitatif. Adapun penelitian ini bertujuan untuk meneliti tentang penerapan sistem informasi akuntansi manajemen terhadap pengendalian kualitas produk pada Holland Bakery Manado, Sulawesi Utara. Tempat penelitian di Holland Bakery Manado yang terletak di Jl. Piere Tendean No. 89, Boulevard Manado Sulawesi Utara. Jenis data yang digunakan pada penelitian ini adalah data kualitatif. Data yang digunakan dalam penelitian ini adalah data primer yang merupakan data yang diperoleh secara langsung dari objek penelitian yang diteliti.

Metode pengumpulan data dalam penelitian ini adalah wawancara dan studi kepustakaan. Metode analisis yang digunakan dalam penelitian ini adalah metode analisis deskriptif yaitu, suatu metode yang sifatnya menguraikan, menggambarkan fakta-fakta secara aktual, serta membandingkan suatu data atau keadaan sehingga dapat menerangkan data tersebut sehingga selanjutnya dapat diambil kesimpulan dan saran bagi perusahaan. Tahapan analisis data dalam penelitian ini adalah sebagai berikut: (1) menganalisa proses penerapan sistem informasi akuntansi manajemen terhadap pengendalian kualitas produk yang digunakan oleh perusahaan; (2) merumuskan kelebihan dan kekurangan dari sistem informasi akuntansi manajemen terhadap pengendalian kualitas produk, apabila perusahaan telah menerapkan Sistem Informasi Akuntansi Manajemen terhadap Pengendalian kualitas Produk dalam perusahaannya atau sebaliknya; dan (3) menarik kesimpulan atas setiap sub pokok pembahasan.

\section{Hasil penelitian dan pembahasan Hasil penelitian}

Holland Bakery sudah menerapkan SIAM terhadap pengendalian kualitas produk dengan menggunakan TQM (Total Quality Management) sebagai alat bantu dalam proses penerapannya.

1. Fokus pada pelanggan. Konsumen/pelanggan merupakan pihak yang sangat penting bagi perusahaan dalam menentukan keberhasilan produk yang dijual. Dengan banyaknya produsen-produsen yang bergerak dibidang pembuatan roti (bakery), maka banyaknya konsumen lebih memilih produk yang harganya bersaing dengan kualitas premium. Holland Bakery menawarkan produk yang berkualitas premium dengan memikirkan dampak positif bagi para pelanggannya.

2. Obsesi Mutu. Holland Bakery menawarkan produk yang berkualitas/bermutu tinggi bagi para konsumennya dengan melakukan pengadaan bahan baku yang berkualitas premium. Setiap bahan baku yang diadakan perusahaan dalam proses produksinya disortir terlebih dahulu oleh bagian produksi dan gudang sehingga bahan baku yang berkualitas premium tersebut dapat diproduksi menjadi produk yang bermutu tinggi.

3. Kerjasama Tim. Produk yang berkualitas baik dapat di capai oleh Holland bakery dengan adanya kerjasama tim. Kerjasama tim yang ada di Holland bakery seperti kerjasama tim dalam proses produksi dan pada proses pemasaran produk. Dengan adanya kerjasama tim yang baik Holland Bakery 
dapat mencapai target penjualan sesuai dengan yang diharapkan yaitu target penjualan harus $100 \%$ per tahunnya.

4. Perbaikan sistem secara berkesinambungan. Holland Bakery memeriksa setiap sistem yang ada apakah sistem tersebut mengalami masalah atau tidak, sehingga setiap pekerjaan yang diakukan di setiap bagian perusahaan dapat berjalan dengan lancar. Perbaikan sistem yang dilakukan secara terus menerus dapat meberikan hasil yang positif bagi Holland Bakery dan perusahaan dapat mencapai tujuannya sesuai dengan kebijakan yang berlaku di perusahaan.

5. Kebebasan yang terkendali. Holland Bakery selalu memberikan kebebasan bagi para karyawannya dalam proses bisnisnya. Kebebasan yang terkendali tersebut diterapkan oleh Holland Bakery berdasarkan pada SOP (Standar Operational Prosedur) yang ada di Holland Bakery.

6. Pendidikan dan pelatiban. Pendidikan dan pelatihan yang dilaksanakan di Holland Bakery yaitu saat dalam proses perekrutan karyawan, Holland Bakery selalu memberikan pelatihan bagi karyawan-karyawan baru sesuai dengan bidang-bidangnya masing-masing. Dengan adanya pendidikan dan pelatihan (masa training) Holland Bakery dapat meningkatkan kualitas produknya, kualitas pelayanannya dan karyawan dapat bekerja sesuai dengan bidangnya.

7. Kesatuan tujuan. Menciptakan produk yang berkualitas baik merupakan tujuan utama dari Holland Bakery. Kesatuan tujuan tersebut dapat dicapai dengan adanya kerjasama tim dan pembagian tugas berdasarkan fungsi dan wewenang dari setiap karyawan yang di Holland Bakery.

8. Keterlibatan karyawan. Adanya keterlibatan dan pemberdayaan karyawan di Holland Bakery dilakukan dalam proses pengambilan keputusan oleh pimpinan terkait dengan kualitas produk yang dihasilkan dan ditawarkan bagi konsumen. Dengan adanya keterlibatan karyawan dalam proses pengambilan keputusan tersebut karyawan dapat bekerja dengan baik dan membuat karyawan mampu menyelesaikan tugas dan tanggung jawabnya demi menghasilkan produk yang berkualitas baik di Holland Bakery.

9. Pendekatan ilmiah. Pemisahan tugas, fungsi dan tanggung jawab dari setiap karyawan di Holland Bakery yaitu dengan memisahkan karyawan berdasarkan kemampuannya di divisidivisi yang sudah. Pemisahan tugas, fungsi dan tanggung jawab tersebut merupakan salah satu cara yang dilakukan perusahaan dalam hal pendekatan ilmiah yang ada di Holland Bakery.

10. Komitmen jangka panjang. Kualitas produk yang baik merupakan salah satu kunci keberhasilan dari produk yang diproduksi. Holland Bakery mengutamakan kualitas produk dan kualitas layanan yang baik bagi konsumen, sehingga Holland Bakery memiliki komitmen yang dipegang teguh demi kelancaran usahanya.

\section{Pembahasan}

Analisis hasil wawancara. Berdasarkan hasil wawancara, didapati bahwa sistem informasi akuntansi manajemen sudah diterapkan di Holland Bakery Manado dengan cara melakukan permintaan oleh sistem dan direkap oleh bagian distribusi dan selanjutnya diproduksi. Untuk kelancaran operasionalnya, Holland Bakery sudah melakukan pemisahan fungsi wewenang dan tanggung jawab, misalnya pada bagian produksi mempunyai divisi masing-masing seperti divisi tart, divisi roti, divisi pastries, divisi kue basah, divisi donat dan divisi bolu. Produk-produk yang dihasilkan di Holland Bakery seperti roti, tart, kue basah, pastries, donat, dan gorengan selalu memperhatikan dan mempertahankan kualitasnya dengan menentukan waktu layak konsumsi untuk pelanggan (customer) dan melakukan pembatalan (reject) pada produk yang tidak sesuai dengan standar perusahaan. Pembatalan (reject) produk sangat jarang terjadi karena Holland Bakery selalu 
memperhatikan kualitas bahan baku yang berkualitas premium atau yang berkualitas tinggi, bahan baku diadakan langsung dari gudang pusat (Jakarta) kecuali sayur, pisang dan telur dari supplier (pemasok) lokal.

Proses penerapan sistem informasi akuntansi manajemen terhadap pengendalian kualitas produk pada Holland Bakery Manado. Berdasarkan hasil penelitian yang telah dilakukan, dalam proses penerapan Sistem Informasi Akuntansi Manajemen terhadap pengendalian kualitas produk pada Holland Bakery Manado, penelitian ini menemukan adanya penerapan TQM dalam kegiatan bisnisnya. Penerapan TQM tersebut dapat dilihat pada Tabel 1.

\begin{tabular}{|c|c|c|c|}
\hline No & $\begin{array}{c}\text { Penerapan TQM di } \\
\text { Holland Bakery } \\
\text { Manado }\end{array}$ & $\begin{array}{c}\text { Sudah } \\
\text { diterapkan }\end{array}$ & $\begin{array}{c}\text { Belum } \\
\text { diterapkan }\end{array}$ \\
\hline 1 & Fokus pada pelanggan & $\checkmark$ & \\
\hline 2 & Obsesi mutu & $\checkmark$ & \\
\hline 3 & $\begin{array}{l}\text { Kerjasama } \\
\text { (teamwork) }\end{array} \quad$ tim & $\checkmark$ & \\
\hline 4 & $\begin{array}{l}\text { Perbaikan sistem secara } \\
\text { berkesinambungan }\end{array}$ & $\checkmark$ & \\
\hline 5 & $\begin{array}{l}\text { Kebebasan yang } \\
\text { terkendali }\end{array}$ & $\checkmark$ & \\
\hline 6 & $\begin{array}{l}\text { Pendidikan dan } \\
\text { pelatihan }\end{array}$ & $\checkmark$ & \\
\hline 7 & Kesatuan tujuan & $\checkmark$ & \\
\hline 8 & $\begin{array}{l}\text { Adanya keterlibatan } \\
\text { dan pemberdayaan } \\
\text { karyawan }\end{array}$ & $\checkmark$ & \\
\hline 9 & Pendekatan ilmiah & $\checkmark$ & \\
\hline 10 & $\begin{array}{l}\text { Komitmen jangka } \\
\text { panjang }\end{array}$ & $\checkmark$ & \\
\hline
\end{tabular}

\section{Kesimpulan dan saran \\ Kesimpulan}

Penerapan sistem informasi akuntansi manajemen terhadap pengendalian kualitas produk di Holland Bakery Manado sudah diterapkan, dengan menggunakan TQM. Dalam proses penerapannya perusahaan seringkali menghadapi kendala-kendala, seperti pada saat permintaan konsumen meningkat kinerja karyawan menurun, dan lain sebagainya. Kendala-kendala tersebut dapat diatasi dengan cara menggunakan sistem pembagian tugas dan tanggung jawab secara terpisah sehingga perusahaan dapat menghasilkan produk yang berkualitas baik. Dengan adanya Penerapan sistem informasi akuntansi manajemen terhadap pengendalian kualitas produk dapat membantu setiap divisi-divisi dalam menjalankan setiap kegiatan pada bagian masing-masing untuk menghasilkan produk yang memenuhi standar kualitas yang telah ditetapkan oleh perusahaan.

\section{Saran}

Holland Bakery sebaiknya terus menerus menerapkan sistem informasi akuntansi manajemen terhadap pengendalian kualitas produk pada setiap divisi-divisi sehingga perusahaan dapat menghasilkan produk yang sesuai dengan standar yang sudah ada. Holland Bakery sebaiknya melakukan perbaikan terhadap sistem informasi akuntansi manajemen yang sudah terkomputerisasi sehingga perusahaan dapat memperkecil resiko kesalahan dalam input data yang tidak sesuai dengan data fisik. Dalam hal pengendalian kualitas produk perusahaan sebaiknya melakukan perbaikan terhadap sistem yang sudah ada dengan melakukan pengendalian internal secara keseluruhan disetiap divisi-divisi sehingga produk yang dihasilkan memiliki kualitas baik, dan dapat meningkatkan keuntungan bagi perusahaan.

\section{Daftar pustaka}

American Accounting Association (AAA). Akuntansi dan sistem informasi. https://ekonomi.sobatmateri.com/definisiakuntansi-menurut-american-accountingassociation/. Diakses pada tanggal 8 maret 2019, jam 1.00.

American Insitute of Certified Public Accounting (AICPA). Pengertian Akuntansi. http://www.akuntansilengkap.com/akuntansi/5 -besar-pengertian-akuntansi-menurut-para-ahli/. Di akses pada tanggal 8 maret 2019, jam 1.20.

Butarbutar, J., D., Karamoy, H., \& Tirayoh, V. Z. (2017). Analisis penerapan sistem akuntansi manajemen terhadap pengendalian kualitas produk di PT Empat Saudara Manado. Going Concer: Jurnal Riset Akuntansi, 12(1), 187-193. http://doi.org/10.32400/gc.12.01.17204.2017.

Hansen, D. R., \& Mowen, M. M. (2012). Akuntansi manajerial. Jakarta: Salemba Empat.

Krismiaji., \& Aryani, Y. A. (2011). Akuntansi manajemen. Yogyakarta: Sekolah tinggi Ilmu Manajemen YKPN.

Kotler, P., \& Keller, K. L. (2009). Manajemen pemasaran. Jakarta: Erlangga. 
Lupiyoadi, R., \& Hamdani, A. (2009). Manajemen pemasaran jasa. Edisi 3. Jakarta: Salemba Empat.

Mawadah, Y., \& Muchayatin, M. (2018). Pengembangan model sistem informasi akuntansi manajemen untuk pengendalian kualitas produk pada PT. Lucky Textile II Semarang. Serat Acitya: Jurnal Ilmiah UNTAG, 7(1), 42-62. http://jurnal.untagsmg.ac.id/index.php/sa/articl e/view/697.

Nasution, M. N. (2015). Manajemen mutu terpadu. Bogor: Ghalia Indonesia.

Tengor, N. L., Ilat, V., \& Tirayoh, V. Z. (2016). Pengaruh sistem akuntansi manajemen terhadap pengendalian kualitas produk pada CV Sarana Marine Fiberglass Manado. Jurnal EMBA, 4(1), 272-282. http://doi.org/10.35794/emba.v4i1.11595.

Tjiptono, F. (2008). Strategi pemasaran. Yogyakarta: ANDI.

Samryn, S. (2012). Pengantar akuntansi. Jakarta: PT Raja Grafindo Persada.

Sujarweni, V. W. (2015). Akuntansi manajemen teori dan aplikasi. Yogyakarta: Pustaka Baru Press.

Sumarsan, T. (2013). Sistem Pengendalian Manajemen, Edisi 2. Jakarta: PT. Indeks.

Supriyono. (2015). Akuntansi manajemen. Yogyakarta: BPFE.

Sutarto, H. P. (2015). Manajemen mutu terpadu (MMTTQM) teori dan penerapan di lembaga pendidikan. Yogyakarta: UNY Press. 